\title{
Study on Reactive Blue Adsorption on Raw and Modified Wheat Straw Using Fixed-Bed Column
}

\author{
Alaa H. Taha ${ }^{1}$, Khalid M. Mousa Al-zobai ${ }^{2 *}$
}

\section{Authors affiliations: \\ 1) Samawa Oil Refinery, Midland Refineries Company, Ministry of Oil, Iraq alaahusseintaha@gmail.com}

2*) Department of Chemical Engineering, Al-Nahrain University, Baghdad, Iraq Khalidmousa15@eng.nahrainu niv.edu.iq

\section{Paper History:}

Received: $9^{\text {th }}$ Jan. 2020

Revised: $16^{\text {th }}$ March 2020

Accepted: 23 ${ }^{\text {rd }}$ Jan. 2021

\begin{abstract}
The intention of this study was to explore the efficiency and feasibility of adsorption of Reactive Blue dye (H3R) used in textile industries using Raw wheat straw (RWS) and Modified wheat straw (MWS) as a low-cost adsorbent. Wheat straw was modified using cationic surfactant (CTAB) to study the improvement of dye removal. The properties of Raw and Modified wheat straw are studied by means of Fourier transform infrared (FTIR) and scanning electron microscope (SEM) analyses to determine the functional groups and the nature of their surface. Continuous experiments were done by fixedbed column to study the characteristics of the breakthrough curve using different bed heights and flow rates. Results showed that the breakthrough time increases with increasing bed height and decreasing flow rate, in turn results into higher removal capacity. Results also showed a higher flow rate lead a lower adsorption capacity due to insufficient residence time. Bed depth service time model (BDST), Adam-Bohart and Thomas models were used to predict the breakthrough curves and to determine the adsorption capacity of the column. The highest bed capacity of 12.95 and $32.2 \mathrm{mg} / \mathrm{g}$ for MWS was obtained using $10 \mathrm{mg} / \mathrm{L}, 10 \mathrm{~cm}$ bed height at $10 \mathrm{~mL} / \mathrm{min}$ and 30 $\mathrm{mL} / \mathrm{min}$ respectively.
\end{abstract}

Keywords: Adsorption, Fixed Bed, Reactive Blue, Wheat Straw

$$
\begin{aligned}
& \text { دراسة امتزاز الصبغة الزرقاء الفعالة على قش الحنطة الطبيعية والمعدلة } \\
& \text { باستخدام عمود الحشوة الثابتة } \\
& \text { علاء حسين طه ، خالد مخلف موسى } \\
& \text { الهدف من هذه الدراسة هو استكشاف فعالية وجدوى امتزاز الصبغة الزرقاء الفعالة (H3R) المستخدمة } \\
& \text { في صناعات النسيج باستخدام قش الحنطة الطبيعية (RWS) وقش الحنطة المعدلة (MWS) كمادة مازةً }
\end{aligned}
$$

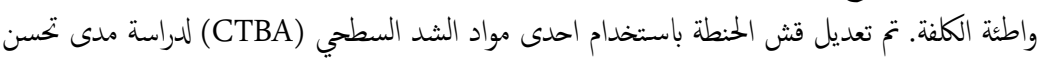

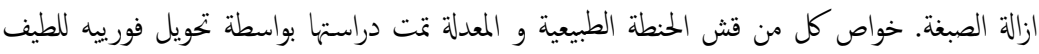

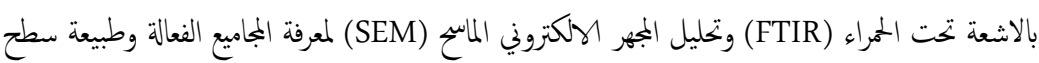

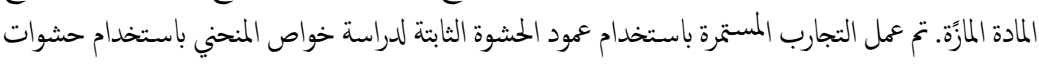

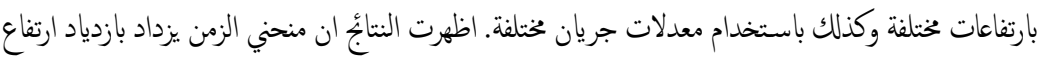

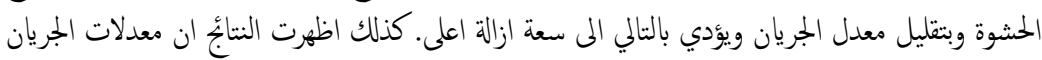

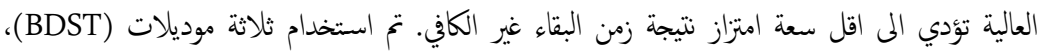

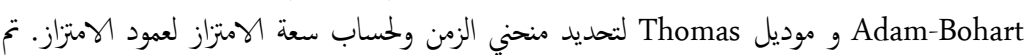

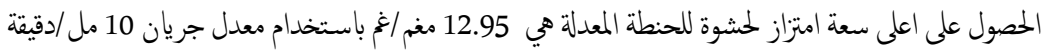

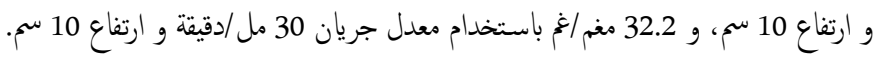

NJES is an open access Journal with ISSN 2521-9154 and eISSN 2521-9162

This work is licensed under a Creative Commons Attribution-NonCommercial 4.0 International License 


\section{Introduction}

A huge amount of water is consuming in textile industry for all the stages of the manufacturing processes. The most polluted water produced from the industrial sectors is from textile plants, considering the quantity as well as the effluent composition [1]. There are a wide range of polluting substances in wastewater producing from textile industry including dyes. Color is the first contaminant and has to be treated before discharging the wastewater. Due to visibility of the small amounts of dyes it has highly effects on the aesthetic of water. The colored dye are highly toxic and it can damage the biota [2]. In general, dye is soluble in water at low concentration. There are three main categories to remove the dyes from polluted water, namely physical, chemical and biological methods [3]. Many techniques were used in the past for removal of dyes from wastewater. Most of the conventional treatment techniques are expensive. The adsorption process is effective method for treating dye-containing effluents. The advantages of this process are, easy operation, less investment, simple design, and free from or less generation of toxic substances [4]. At present, there are many researchers focus on using low cost, commercial and available materials for the adsorption of dyes. The agricultural wastes (wheat straw ) are an available, renewable and less expensive as compared to other materials used as adsorbents [5]. (Annadurai et al. 2013) used banana and orange peels as a low-cost adsorbent. The results showed that the banana peel was more effective than orange peel [6]. (Robinson et al. 2002) studied the adsorption process using two low-cos adsorbents; apple pomace and wheat straw for textile dye removal [7]. (Santhy and Selvapathy 2006) studied the removal efficiency of activated carbon prepared from coir pith to remove the reactive dyes in textile industry using batch and column processes [8]. (Dizge et al. 2008) ivestegated the adsorption of three reactive dyes from aqueous solutions using fly ash [9]. (Hameed 2009) stated that the spent tea leaves can be used as adsorbent for the cationic dye (methylene blue)[10]. (Said et al. 2013) Removed reactive yellow 2 and reactive blue using bagasse [11]. The continuous adsorption in fixed-bed column is often desired from industrial point of view. It is simple to operate and can be scaled-up from a laboratory process. In this study we used an agricultural waste as an adsorbent with a chemical modification and compare the results.

The aim of this study is design a continuous adsorption system in order to removes of Reactive Blue dye (H3R) using Bed Depth Service Time model (BDST), Adam-Bohart model and Thomas model using locally available adsorbent which are Raw Wheat Straw (RWS), Modified Wheat Straw (MWS) and comparing the performance of (RWS) and (MWS) in decolorizing.

\section{Column adsorption models}

The breakthrough curve or concentration profile under the given operating conditions is the key to design a column adsorption process. The significant parameter for any sorption system is the maximum adsorption capacity. A number of mathematical models were developed to find the efficiency and applicability of the column models for large-scale operations. In this study BDST, Adams - Bohart and Thomas Models were used to analysis the behavior of adsorbent-adsorbate system. Equation 1 was used to calculate the amount of adsorbed dye $q_{\text {total }}(\mathrm{mg})$ for a given flow rate, influent concentration and bed height:

$q_{\text {total }}=\frac{Q}{1000} \int_{t=0}^{t=t} C_{a d} d t$

Where $\mathrm{Q}$ is the volumetric flow rate $(\mathrm{mL} / \mathrm{min})$, $\mathrm{t}$ is the total time taken for the flow of solution (min), and Cad is the concentration of adsorbed dye $(\mathrm{mg} / \mathrm{L})$. The equilibrium adsorption of the column qeq $(\mathrm{mg} / \mathrm{g})$ can be calculated as followed:

$q_{e q}=\frac{q_{\text {total }}}{w}$

Where $\mathrm{w}$ is the amount of adsorbent in the column $(\mathrm{g})$. [12].

\subsection{Bed depth service time model (BDST)}

BDST is a model describes the relationship between the service time $(t)$ and the bed depth in terms of process concentrations and adsorption parameters. Bed depth service time model is used only for the description of the first part of the breakthrough curve, i.e. up to the breakpoint or $10-50 \%$ of the saturation points [12]. The surface reaction between adsorbate and the unused capacity of the adsorbent is the assumption that the rate of adsorption is controlled equation 3 is used to calculate t.

$t=\frac{N_{o}}{C_{o} u} D-\frac{1}{K_{B} C_{o}} \ln \left(\frac{C_{o}}{C_{t}}-1\right)$

Where $t$ is the service time of column (min), $N_{o}$ the adsorption capacity $(\mathrm{mg} / \mathrm{L}), D$ is the bed depth of column $(\mathrm{cm}), K_{B}$ the adsorption rate constant (L/mg.min), $C_{o}$ is the initial concentration of solute $(\mathrm{mg} / \mathrm{L}), C_{t}$ the desired concentration of solute at breakthrough $(\mathrm{mg} / \mathrm{L}), \quad u$ is the superficial liquid velocity of feed to bed $(\mathrm{cm} / \mathrm{min})$. A plot of $t$ versus bed depth $D$ should yield a straight line where $N_{o}$ and $K_{B}$ the adsorption capacity and rate constant, respectively, can be evaluated [12].

\subsection{Adam-Bohart model}

The concentration of the sorbing species and residual capacity of the adsorbent are affected the adsorption rate when using this model. The characteristic parameters such as saturation concentration No and the kinetic constant $\mathrm{Ka}$ were estimated in this model [13]. The fraction that remains on the surface of the adsorbent is the driving force of the rate of adsorption is proportional. The AdamsBohart model describes a relationship between the normalized concentration $(\mathrm{Ct} / \mathrm{Co})$ and the bed height $(\mathrm{H})$ equation 4 described this model:

$\ln \left(\frac{C_{t}}{C_{o}}\right)=K_{A} C_{o} t-\frac{K_{A} N_{o}}{u} H$

Where, $C_{o}$ and $C_{t}$ are the initial and breakthrough concentration $(\mathrm{mg} / \mathrm{L})$ respectively , $K_{A}$ is the Adam- 
Bohart constant $(\mathrm{L} / \mathrm{mg} \cdot \mathrm{min}), t$ is the breakthrough time (min),$N_{o}$ is the adsorption capacity of the adsorbent in $(\mathrm{mg} / \mathrm{L}), u$ is the linear velocity in $(\mathrm{cm} / \mathrm{min})$ and and $H$ is the bed depth in $(\mathrm{cm})$, [14].

\subsection{Thomas model}

One of the most commonly used models in fixed bed adsorption processes is Thomas models. This model assumed that the process follows Langmuir theory of adsorption-desorption and there is no axial dispersion. Thomas model also assumes that the constant separation factor is applicable to either favorable or unfavorable isotherm [15]. The kinetic model presented by Thomas is of the form:

$$
\frac{C}{C_{o}}=\frac{1}{1+\exp \left[\frac{k}{Q}\left(q_{o} M-C_{o} V\right)\right]}
$$

Where $\mathrm{C}$ and $\mathrm{Co}$ are the effluent and the influent concentrations respectively $(\mathrm{mg} / \mathrm{L}), \mathrm{Q}$ is the volumetric flow rate, $\mathrm{k}$ is Thomas rate constant ( $\mathrm{L} / \mathrm{mg} \cdot \mathrm{min}), \mathrm{M}$ is mass of adsorbent $(\mathrm{g})$, qo is the maximum capacity $(\mathrm{mg} / \mathrm{g}$ ) and $\mathrm{V}$ is the throughput volume (L).

\section{Material and Work}

\subsection{Adsorbate}

Reactive Blue dye (H3R) with wavelength (585 nm) and molecular weight $(562) \mathrm{g} / \mathrm{mol}$ and is supplied from Al-Hilla textile factory south of Baghdad. Figure (1) shows the chemical structure of Reactive Blue.

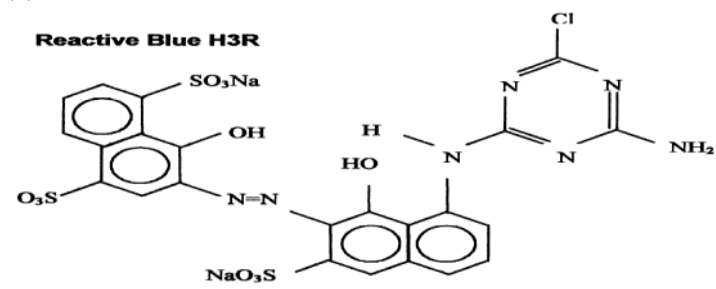

Figure (1): Chemical structure of Reactive Blue

\subsection{Adsorbents}

Wheat straw (RWS) and modified wheat straw (MWS) were used as adsorbents. The adsorbents are washed with distilled water and dried for 24 hours at $70{ }^{\circ} \mathrm{C}$ then, sieved to the desired particle size $(1 \mathrm{~mm})$. Glass container was used for stored the sample and. Cetyl-trimethylammonium bromide (CTAB) was used for modified by mixing $35 \mathrm{~g}$ of wheat straw with $4 \mathrm{~g} / 1$ of $500 \mathrm{~mL}$ of (CTAB) solution. Shaker was used to mixing the solution under room temperature for 5 hours. Distilled water was used for washing in order to remove any loosely adsorbed surfactant then dried to $70{ }^{\circ} \mathrm{C}$ and sieved. It's worthy to stated that to increase the attraction between the dye molecules and the surface of the adsorbent the CTAB was used because its change the charge of the adsorbent [16].

\subsection{Experimental set-up}

The rates of adsorption depend on the concentration of solute in the solution being treated in Continuous-flow operations. For column operation, the adsorbent is continuously in contact with a fresh solution. Dynamic flow mode biosorption performance of the biosorbent was investigated by pumping the reactive blue dye solution using a peristaltic pump into a rotameter to adjust the flow rate at 10 and $30 \mathrm{~mL} / \mathrm{min}$ where the solution is fed to the adsorber using small-scale cylindrical fixed-bed column I.D $2.5 \mathrm{~cm}$ and with a height of $50 \mathrm{~cm}$.

A sample was packed with three different bed heights 10,15 and $25 \mathrm{~cm}$ between two layers of glass wool into the column. The effluent samples were taking every $(30 \mathrm{~min}$ ) and measured for the dye concentration by UV/Visible spectrophotometer. The flow to the column was continued until the effluent concentration (Ce) approached the influent concentration (Co). Figure (2) shows a schematic design of continuous adsorption process.

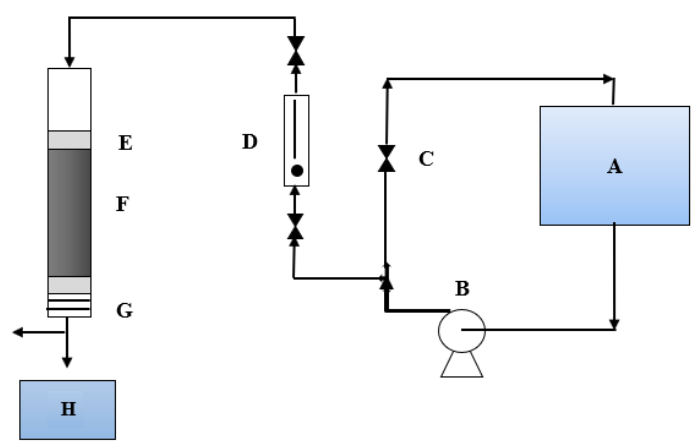

Figure (2): Schematic design of continuous adsorption set up

\section{Results and Discussion \\ 4.1. FTIR analysis}

FTIR was used for identification for the gropes responsible for the adsorption process. The region of test was $400-4000 \mathrm{~cm}-1$ [17]. Figure (3) shows the FTIR analysis. From Figure it's clear that the structure of the surface is complex. The peaks indicate the complex structure of wheat straw. The peaks of1427 and $1373 \mathrm{~cm}-1$ associated with the $\mathrm{C}-\mathrm{O}$ in phenols and $-\mathrm{CH} 3$ respectively. The peaks of 1732 and $1655 \mathrm{~cm}-1$ are referring to the carbonyl group $-\mathrm{C}=\mathrm{O}, 1508 \mathrm{~cm}-1$ represents the aromatic rings. While the strong peak around $3414 \mathrm{~cm}-1$ represents the hydroxyl groups $\mathrm{OH}$, the bond at $2916 \mathrm{~cm}-1$ is attributed to the presence of the C-H bond. [18], [19].

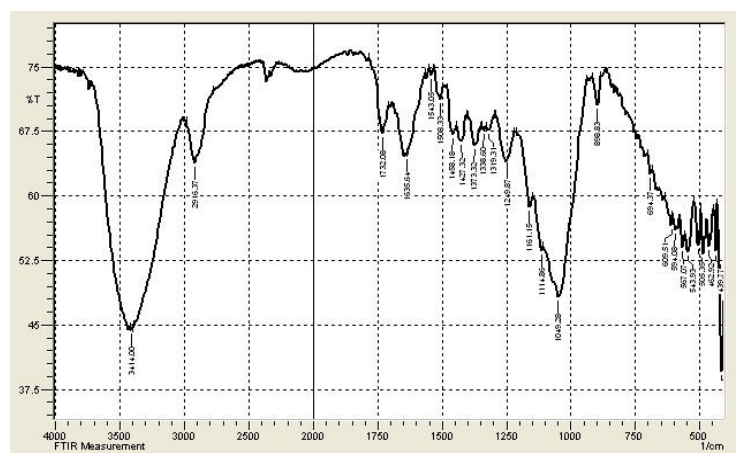

Figure (3): FTIR analysis of Raw wheat straw (RWS) 


\subsection{Scanning Electron Microscope (SEM)}

SEM is used to show if the surface of RWS and MWS are heterogeneous or homogeneous and check their porosity. Figures 4 (a and b) show the SEM analysis of both RWS and MWS. From Figure (4) (b) it's clear that the activation process is greatly improved the structure of the modified Wheat straw due to several porous presence. The adhering adsorbate molecules will be more due to a high surface area for [20]. The detailed of FTIR and SEM are shown in our previous works [24] and [25].

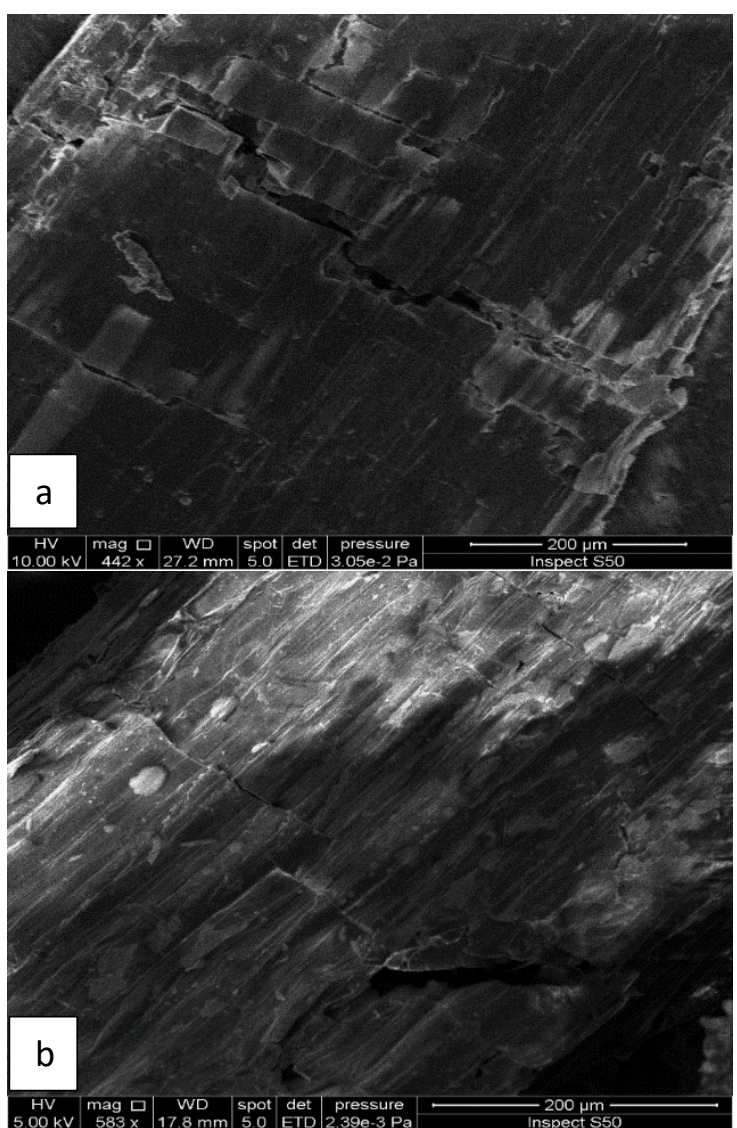

Figure (4): SEM microscope (a): RWS, (b): MWS

\subsection{Continuous Experiments}

Experimental breakthrough curves were conducted to study characteristics of a fixed-bed column. A normalized Figure have to be done to describes the loading behavior of the adsorbate on a fixed-bed column. The initial adsorbate concentration $(\mathrm{Ct} / \mathrm{Co})$ as a function of time for a given bed height or adsorbate flow rate must draw [21]. Figures (5) and (6) show the breakthrough curves of Reactive blue using RWS and MWS adsorbents. The breakthrough generally occurred faster with higher flow rate. The breakthrough time reaching saturation was increased considerably with a decreased in the flow rate. As shown in Figures (4) and (5), due to insufficient residence time of the solution in the column and diffusion of the solute into the adsorbent pores the adsorption capacity was lower at a higher flow rate. It's clear from Figures that that the adsorption capacity is low in the case of RWS because of the low surface area in comparing to MWS. The increasing in the bed height will increasing the time of breakthrough curve, this attributed to that the increase in bed height will increase the contact time between the dye and the RWS and MWS. The increasing of bed meaning increasing in mass transfer zone and this led to a higher removal capacity and lower solute concentration in the effluent. At the highest bed due to an increase in the surface area of adsorbent a high adsorption capacity was observed because more binding sites for the adsorption [22].

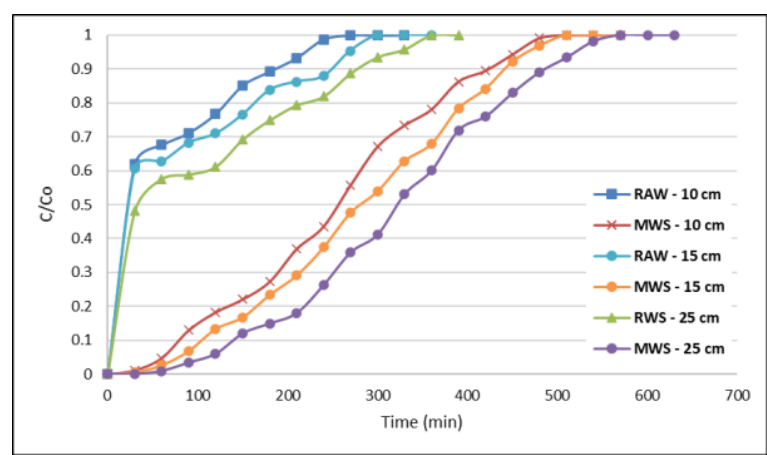

Figure (5): Breakthrough curve of Reactive Blue using RWS and MWS, $\mathrm{pH}=6.8, \mathrm{Co}=10 \mathrm{mg} / \mathrm{L}$, flow rate $=10 \mathrm{~mL} / \mathrm{min}$ and bed height $=10,15$ and $25 \mathrm{~cm}$

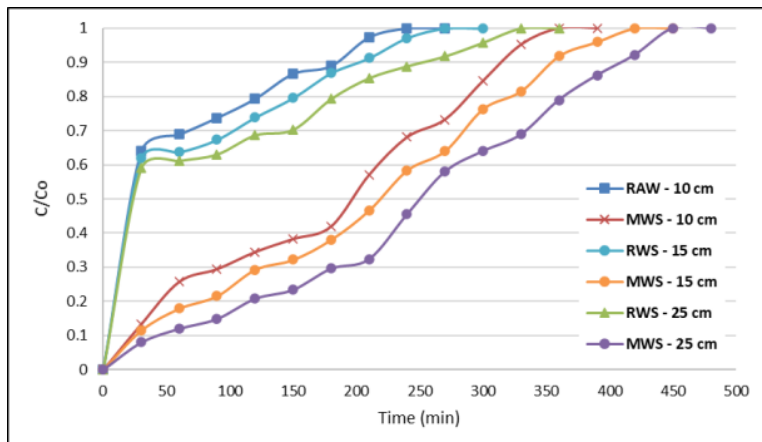

Figure (6): Breakthrough curve of Reactive Blue using RWS and MWS, $\mathrm{pH}=6.8, \mathrm{C}_{o}=10 \mathrm{mg} / \mathrm{L}$, flow rate $=30 \mathrm{~mL} / \mathrm{min}$ and bed height $=10,15$ and $25 \mathrm{~cm}$

\subsection{Modeling and analysis of data column 4.4.1. Bed Depth Service Time model (BDST)}

Figure (7) shows the BDST model by applying Eq. (3) for RWS and MWS using $10 \mathrm{~mL} / \mathrm{min}$ flow rate. Table 1 shows the BDST model parameters using 10 and $30 \mathrm{~mL} / \mathrm{min}$ flow rates. From Table (1), it is apparent that with increase in flow rate, the adsorption capacity No and kinetic constant KB increased, this indicated that in the initial part of biosorption, the overall system kinetics was dominated by external mass transfer for all the adsorbents [23]. 


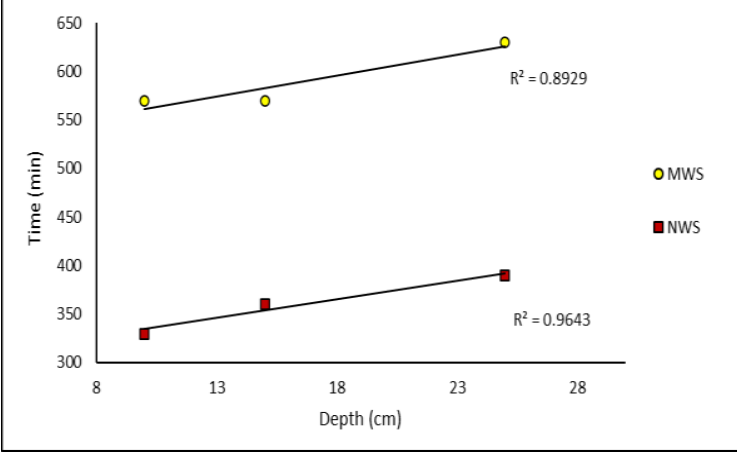

Figure (7): BDST model of Reactive Blue using RWS and MWS

Table (1): Bed depth service time model parameters of Reactive Blue.

\begin{tabular}{|c|c|c|c|c|c|c|c|}
\hline \multirow{2}{*}{$\begin{array}{l}\text { Flow rate } \\
(\mathrm{mL} / \mathrm{min})\end{array}$} & \multirow{2}{*}{$\begin{array}{c}\text { Adsorbent } \\
\text { Bed height } \\
\text { (cm) }\end{array}$} & \multicolumn{3}{|c|}{ RWS } & \multicolumn{3}{|c|}{ MWS } \\
\hline & & 10 & 20 & 25 & 10 & 20 & 25 \\
\hline \multirow{3}{*}{10} & $\mathrm{~N}_{\circ}(\mathrm{mg} / \mathrm{L})$ & \multicolumn{3}{|c|}{78.68} & \multicolumn{3}{|c|}{87} \\
\hline & $\begin{array}{c}\mathrm{K} * 10^{4} \\
(\mathrm{~L} / \mathrm{mg} \cdot \min )\end{array}$ & \multicolumn{3}{|c|}{7.0} & \multicolumn{3}{|c|}{4.2} \\
\hline & $\mathbf{R}^{2}$ & \multicolumn{3}{|c|}{0.964} & \multicolumn{3}{|c|}{0.893} \\
\hline \multirow{3}{*}{30} & $\mathrm{~N}_{\circ}(\mathrm{mg} / \mathrm{L})$ & \multicolumn{3}{|c|}{235.7} & \multicolumn{3}{|c|}{347.1} \\
\hline & $\begin{array}{c}\mathrm{K}^{* 10^{4}} \\
(\mathrm{~L} / \mathrm{mg} \cdot \mathrm{min})\end{array}$ & \multicolumn{3}{|c|}{9.0} & \multicolumn{3}{|c|}{6.3} \\
\hline & $\mathbf{R}^{2}$ & \multicolumn{3}{|c|}{0.965} & \multicolumn{3}{|c|}{0.862} \\
\hline
\end{tabular}

\subsubsection{Adam-Bohart model}

In order to provide a simple and comprehensive approach for running and evaluating sorption-column tests Adams-Bohart model was used. The validity of this model is limited to the range of conditions used. Figure (8) shows the Adam-Bohart model fitting of two adsorbents. Table (2) shows the parameters of Adam-Bohart model using Eq. (4). The values of KA decreased with flow rate increase and it increased with increasing bed heights. This showed that the overall system kinetics was dominated by external mass transfer in the initial part of adsorption in the column [23]. The regression shows a high correlation fitting with RWS while shows a good fitting of MWS indicating that this model is appropriate for the initial part of adsorption process which is controlled by the mass transfer. [24].

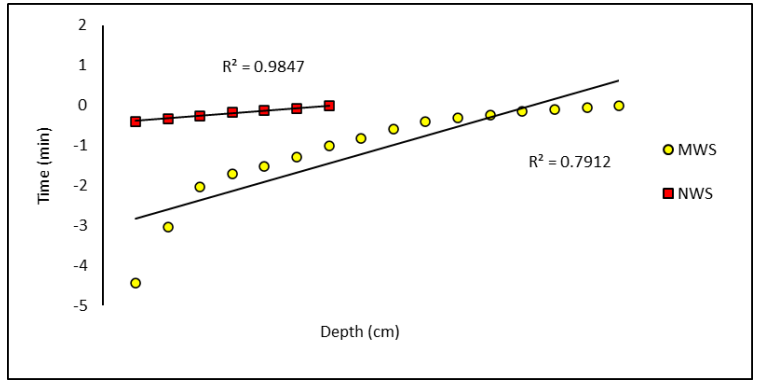

Figure (8): Adam - Bohart model of Reactive Blue using RWS and MWS
Table (2): Adam - Bohart model parameters of Reactive Blue

\begin{tabular}{|c|c|c|c|c|c|c|c|}
\hline \multirow{2}{*}{$\begin{array}{l}\text { Flow rate } \\
(\mathrm{mL} / \mathrm{min})\end{array}$} & \multirow{2}{*}{\begin{tabular}{|c|}
$\begin{array}{c}\text { Adsorbe } \\
\text { nt }\end{array}$ \\
$\begin{array}{c}\text { Bed } \\
\text { height } \\
\text { (cm) }\end{array}$ \\
\end{tabular}} & \multicolumn{3}{|c|}{ RWS } & \multicolumn{3}{|c|}{ MWS } \\
\hline & & 10 & 20 & 25 & 10 & 20 & 25 \\
\hline \multirow{3}{*}{10} & $\begin{array}{c}\mathrm{N}_{\mathrm{o}} \\
(\mathrm{mg} / \mathrm{L})\end{array}$ & 492 & 401 & 270 & 820 & $\begin{array}{c}554 . \\
7\end{array}$ & $\begin{array}{c}350 . \\
2\end{array}$ \\
\hline & $\begin{array}{c}\mathrm{K}^{*} 10^{4} \\
(\mathrm{~L} / \mathrm{mg} \cdot \mathrm{mi} \\
\mathrm{n})\end{array}$ & 2.2 & 1.9 & 2.2 & 7.6 & 8.9 & 8.1 \\
\hline & $\mathrm{R}^{2}$ & $\begin{array}{c}0.99 \\
8\end{array}$ & $\begin{array}{c}0.98 \\
4\end{array}$ & $\begin{array}{c}0.97 \\
3\end{array}$ & $\begin{array}{c}0.78 \\
1\end{array}$ & $\begin{array}{c}0.80 \\
4\end{array}$ & $\begin{array}{c}0.84 \\
8\end{array}$ \\
\hline \multirow{3}{*}{30} & $\begin{array}{c}\mathrm{N}_{\mathrm{o}} \\
(\mathrm{mg} / \mathrm{L})\end{array}$ & 7480 & 5100 & 5600 & 1950 & 1460 & 958 \\
\hline & $\begin{array}{c}\mathrm{K}^{*} 10^{4} \\
(\mathrm{~L} / \mathrm{mg} \cdot \mathrm{mi} \\
\text { n) }\end{array}$ & 2.3 & 2.3 & 2.0 & 5.8 & 5.7 & 6.2 \\
\hline & $\mathrm{R}^{2}$ & 0.99 & 0.99 & 0.98 & $\begin{array}{c}0.94 \\
7\end{array}$ & $\begin{array}{c}0.96 \\
3\end{array}$ & $\begin{array}{c}0.96 \\
5\end{array}$ \\
\hline
\end{tabular}

\subsubsection{Thomas model}

The Thomas parameters, adsorption capacity qcal, $\mathrm{q}_{\exp }$, rate constant $\mathrm{KT}$ and correlation coefficient values are illustrated in Table (3), as shown in table the rate constant $K_{T}$ is increased with increasing bed height and flow rate and the adsorption capacity qcal $_{\text {is }}$ decreased with increasing bed height and increased with increasing the flow rate. Figures (9)-(12) show the Thomas model for both RWS and MWS using different bed heights.

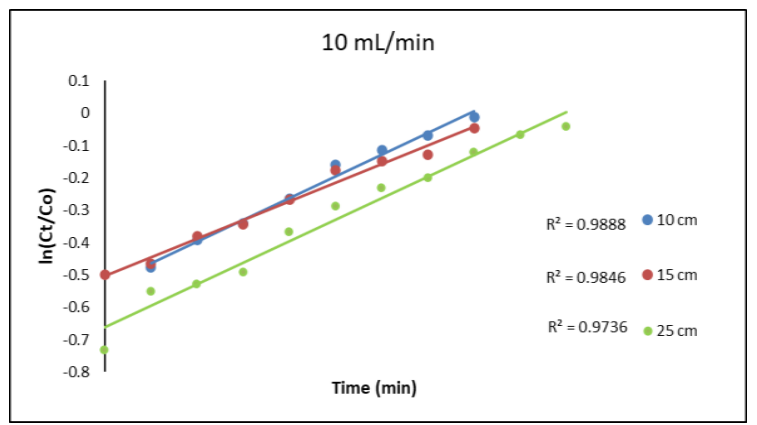

Figure (9): Thomas model of Reactive Blue using RWS, $10 \mathrm{~mL} / \mathrm{min},(10,15,25 \mathrm{~cm})$

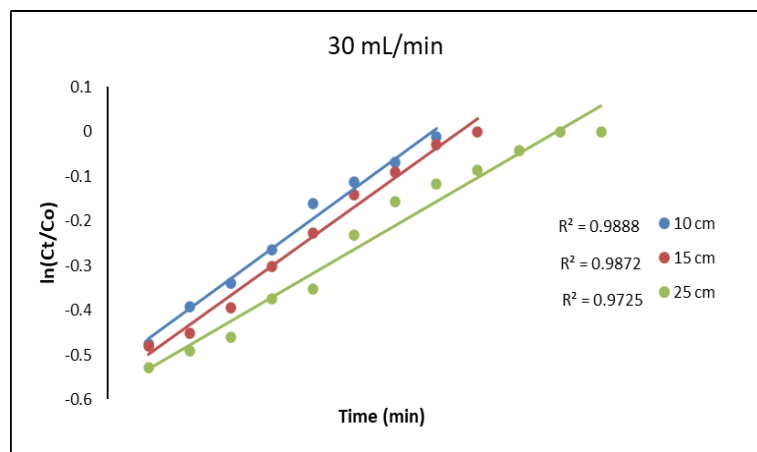

Figure (10): Thomas model of Reactive Blue using RWS, $30 \mathrm{~mL} / \mathrm{min},(10,15,25 \mathrm{~cm})$ 


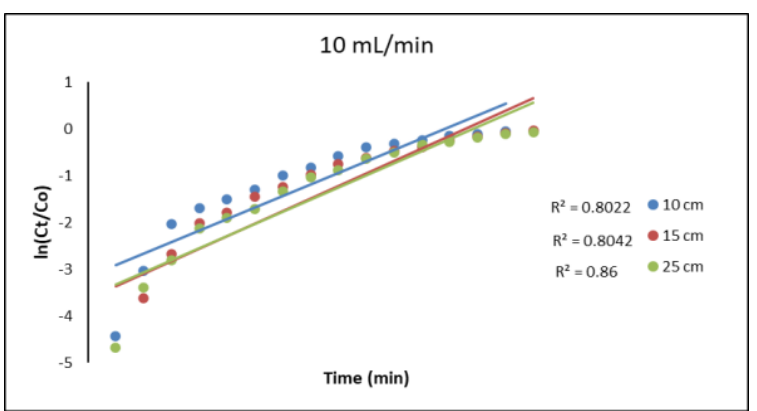

Figure (11): Thomas model of Reactive Blue using MWS, $10 \mathrm{~mL} / \mathrm{min},(10,15,25 \mathrm{~cm})$

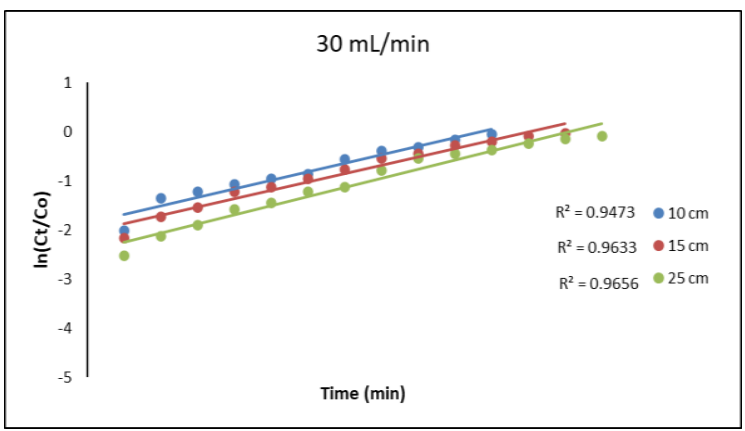

Figure (12): Thomas model of Reactive Blue using MWS, $30 \mathrm{~mL} / \mathrm{min},(10,15,25 \mathrm{~cm})$

Table (3): Thomas model parameters of Reactive Blue

\begin{tabular}{|c|c|c|c|c|c|c|c|}
\hline \multirow{2}{*}{$\begin{array}{c}\text { Flow } \\
\text { rate } \\
(\mathrm{mL} / \mathrm{min} \\
)\end{array}$} & \multirow{2}{*}{$\begin{array}{c}\text { Adsorbent } \\
\text { Bed } \\
\text { height } \\
\text { (cm) }\end{array}$} & \multicolumn{3}{|c|}{ RWS } & \multicolumn{3}{|c|}{ MWS } \\
\hline & & 10 & 20 & 25 & 10 & 20 & 25 \\
\hline \multirow{4}{*}{10} & $\underset{(\mathbf{m g} / \mathbf{g})}{q_{\exp }}$ & 3.8 & 2.7 & 2.62 & $\begin{array}{c}16.9 \\
5\end{array}$ & 11.2 & 7.8 \\
\hline & $\mathrm{q}_{\mathrm{cal}}(\mathrm{mg} / \mathrm{g})$ & 8.94 & 6.77 & 4.65 & $\begin{array}{c}12.9 \\
5\end{array}$ & 9.07 & 6.11 \\
\hline & $\begin{array}{c}\mathrm{K}^{\star} 10^{4} \\
(\mathrm{~L} / \mathrm{mg} \cdot \min \\
\quad)\end{array}$ & 2.2 & 1.9 & 2.2 & 8.2 & 8.9 & 8.6 \\
\hline & $\mathrm{R}^{2}$ & $\begin{array}{c}0.98 \\
8\end{array}$ & $\begin{array}{c}0.98 \\
4\end{array}$ & $\begin{array}{c}0.97 \\
3\end{array}$ & $\begin{array}{c}0.80 \\
2\end{array}$ & $\begin{array}{c}0.80 \\
4\end{array}$ & 0.86 \\
\hline \multirow{4}{*}{30} & $\underset{(\mathrm{mg} / \mathrm{g})}{q_{\text {exp }}}$ & 9.6 & 7.12 & 5.7 & $\begin{array}{c}31.4 \\
7\end{array}$ & 24.8 & $\begin{array}{c}17.0 \\
5\end{array}$ \\
\hline & $q_{\mathrm{cal}}(\mathrm{mg} / \mathrm{g})$ & 24.7 & 17.3 & 12.8 & 32.2 & 23.9 & 16.1 \\
\hline & $\begin{array}{c}\mathrm{K}^{\star} 10^{4} \\
(\mathrm{~L} / \mathbf{m g} \cdot \min \\
)\end{array}$ & 2.3 & 2.3 & 2.0 & 5.8 & 5.7 & 6.2 \\
\hline & $\mathrm{R}^{2}$ & $\begin{array}{c}0.99 \\
3\end{array}$ & $\begin{array}{c}0.98 \\
9\end{array}$ & 0.98 & $\begin{array}{c}0.94 \\
7\end{array}$ & $\begin{array}{c}0.96 \\
3\end{array}$ & $\begin{array}{c}0.96 \\
5\end{array}$ \\
\hline
\end{tabular}

\section{Conclusion}

The investigation showed that the Modified wheat straw using CTAB cationic surfactant was a promising for Reactive Blue dye removal from aqueous solution using fixed-bed adsorption column. The highest breakthrough time was found at $10 \mathrm{~cm}$ bed height with flow rate of $10 \mathrm{~mL} / \mathrm{min}$ for MWS. The highest maximum bed capacity was obtained at a lower bed height $10 \mathrm{~cm}$ and $10,30 \mathrm{~mL} / \mathrm{min}$. Fixed-bed models showed a good fitting with the experimental data for MWS. RWS showed a good regression data fitting with
BDST model for $10 \mathrm{~mL} / \mathrm{min}(\mathrm{R} 2=0.964)$ and 30 $\mathrm{mL} / \mathrm{min}(\mathrm{R} 2=0.965)$. RWS also showed a highly fitted regression with Adam-Bohart model and Thomas model. MWS regression is highly fitted with Thomas model.

\section{References:}

[1] F. M. Drumond Chequer, G. A. R. de Oliveira, E. R. Anastacio Ferraz, J. Carvalho, M. V. Boldrin Zanoni, and D. P. de Oliveir, "Textile Dyes: Dyeing Process and Environmental Impact," in Eco-Friendly Textile Dyeing and Finishing, 2013, pp. 151-176.

[2] S. V Mohan, N. C. Rao, and J. Karthikeyan, "Adsorptive removal of direct azo dye from aqueous phase onto coal-based sorbents: a kinetic and mechanistic study," J. Hazard. Mater., vol. 90, p. 189, 2002, Accessed: Feb. 21, 2018. [Online]. Available:

https://www.sciencedirect.com/science/article/p ii/S030438940100348X.

[3] R. T. Al-Khateeb and A. H. Taha, "Kinetics and isotherm studies of disperse red dye using activated carbon," Go.Galegroup.Com, vol. 17, no. 10, pp. 3035, 2016, Accessed: Feb. 21, 2018. [Online]. Available:

http://go.galegroup.com/ps/i.do?id=GALE\%7C A 491983862\&sid $=$ googleScholar\&v $=2.1 \& i t=r \& l i$ nkaccess $=$ fulltext\&issn $=19950772 \& p=$ AONE\&s $\mathrm{w}=\mathrm{w}$.

[4] U. Ashadevi, V. P. Immanuel, and T. Usharani, "Fixed bed column study for the removal of reactive red $120(\operatorname{Rr} 120)$ dye from aquatic environment by low cost adsorbents," in Proceedings of the International Conference on Green Technology and Environmental Conservation, GTEC-2011, 2011, pp. 347-355, doi: 10.1109/GTEC.2011.6167692.

[5] G. Z. Kyzas, J. Fu, and K. A. Matis, “The change from past to future for adsorbent materials in treatment of dyeing wastewaters," Materials (Basel)., vol. 6, no. 11, pp. 5131-5158, 2013, doi: 10.3390/ma6115131.

[6] V. M. Correia et al., "Cationic Polyelectrolytes as Primary Coagulants for Municipal Wastewater Treatment," J. Hazard. Mater., vol. 6, no. 1, pp. 3741, Feb. 2013, doi: 10.1080/19443994.2013.782256.

[7] T.Robinson, B.Chandran, and P.Nigam, "Removal of dyes from a synthetic textile dye effluent by biosorptin on apple pomace and wheat straw," Water Res., vol. 36, pp. 2824-2830, 2002, Accessed: Feb. 21, 2018. [Online]. Available: https://www.sciencedirect.com/science/article/p ii/S0043135401005218.

[8] K. Santhy and P. Selvapathy, "Removal of heavy metals from wastewater by adsorption on coir pith activated carbon," Sep. Sci. Technol., vol. 39, no. 14, pp. 3331-3351, 2006, doi: 10.1081/SS-200036561.

[9] N. Dizge, C. Aydiner, E. Demirbas, M. Kobya, and S. Kara, "Adsorption of reactive dyes from aqueous solutions by fly ash: Kinetic and equilibrium studies," J. Hazard. Mater., vol. 150, no. 3, pp. 737-746, 2008, doi: 10.1016/j.jhazmat.2007.05.027. 
[10] B. H. Hameed, "Spent tea leaves: A new nonconventional and low-cost adsorbent for removal of basic dye from aqueous solutions," J. Hazard. Mater., vol. 161, no. 2-3, pp. 753-759, 2009, doi: 10.1016/j.jhazmat.2008.04.019.

[11] A. E.-A. A. Said et al., "Application of Modified Bagasse as a Biosorbent for Reactive Dyes Removal from Industrial Wastewater," J. Water Resour. Prot., vol. 05, no. 07, pp. 10-17, 2013, doi: 10.4236/jwarp.2013.57A003.

[12] M. Bhagat, "Adsorptive Removal of Congo Red Dye from Aqueous Solutions by Activated Carbon Columns," J. Urban Environ. Eng., vol. 6, no. 1, pp. 18-29, 2017, doi: 10.4090/juee.2012.v6n1.018029.

[13] M. Trgo, N. Vukojevi, and J. Peri, "Application of mathematical empirical models to dynamic removal of lead on natural zeolite clinoptilolite in a fixed bed column," vol. 18, no. March, pp. 123 131, 2011, Accessed: Feb. 21, 2018. [Online].Available:

http://nopr.niscair.res.in/handle/123456789/116 21.

[14] M. Dutta, J. K. Basu, M. H. Faraz, N. Gautam, and A. Kumar, "Fixed-bed Column Study of Textile Dye Direct Blue 86 by using A Composite Adsorbent," Arch. Appl. Sci. Res., vol. 4, no. 2, pp. 882-891, 2012.

[15] M. T. Yagub, T. K. Sen, S. Afroze, and H. M. Ang, "Dye and its removal from aqueous solution by adsorption: A review," Elsevier, vol. 209, pp. 172-184, 2014, doi: 10.1016/j.cis.2014.04.002.

[16] Reza Ansari and Babak Seyghali, "Application of Wood Sawdust Modified with Cationic Surfactants for Efficient Removal of Acidic Dyes from Aqueous Solutions: Kinetic and Thermodynamic Studies," Eur. Chem. Bull., vol. 2, pp. 499-506, 2013.

[17] S. Tunali Akar, A. Gorgulu, T. Akar, and S. Celik, "Decolorization of Reactive Blue 49 contaminated solutions by Capsicum annuum seeds: Batch and continuous mode biosorption applications," Chem.
Eng. J., vol. 168, no. 1, pp. 125-133, 2011, doi: 10.1016/j.cej.2010.12.049.

[18] Y. Su, Y. Jiao, C. Dou, and R. Han, "Biosorption of methyl orange from aqueous solutions using cationic surfactant-modified wheat straw in batch mode," Desalin. W ater Treat., vol. 52, no. 31-33, pp. 6145-6155, Sep. 2014, doi: 10.1080/19443994.2013.811121.

[19] A. Ebrahimian Pirbazari, E. Saberikhah, and S. S. S. Habibzadeh Kozani, "Fe3O4-wheat straw: Preparation, characterization and its application for methylene blue adsorption," Water Resour. Ind., vol. 7-8, pp. 23-37, 2014, doi: 10.1016/j.wri.2014.09.001.

[20] V. V. Ranade, V. M. Bhandari, and S. Ahirrao, Industrial Wastewater Treatment, Recycling and Reuse. 2014.

[21] F. Cicek, D. Ozer, A. Ozer, and A. Ozer, "Low cost removal of reactive dyes using wheat bran," $J$. Hazard. Mater., vol. 146, pp. 408-416, 2007, doi: 10.1016/j.jhazmat.2006.12.037.

[22] A. A. Ahmad and B. H. Hameed, "Fixed-bed adsorption of reactive azo dye onto granular activated carbon prepared from waste," J. Hazard. Mater., vol. 175, no. 1-3, pp. 298-303, 2010, doi: 10.1016/j.jhazmat.2009.10.003.

[23] C. Umpuch and S. Sakaew, "Removal of commercial blue dye from water onto Chitosancoated-Montmorillonite in fixed bed Abstract The study was to investigate the removal of commercial blue dye from water onto chitosancoated-montmorillonite clay ( CTS / MMT) using fixed bed adso," chem.eng.psu.ac.th, pp. 1-5, 2011, Accessed: Feb. 21, 2018.[Online]. Available: http://www.chem.eng.psu.ac.th/tiche2011/TCH E/data/paper/thai/tes/oral/tes011.pdf.

[24] M. L. Wenqing Wang and Qingxuan Zeng, "Adsorption of chromium (VI) by strong alkaline anion exchange fiber in a fixed-bed column: Experiments and models fitting and evaluating," Sep. Purif. Technol., vol. 149, pp. 16-23, 2015. 